Pre-author query version, please see final journal version

https://doi.org/10.1080/24694452.2020.1749023

In Annals of the American Association of Geographers

\title{
Green Structural Adjustment in the World Bank's Resilient City
}

\begin{abstract}
:
According to an increasingly prevalent set of discourses and practices within environmental and development finance, cities across the Global South are facing a costly infrastructural crisis stemming from rapid urbanization and climate change that threatens to further entrench poverty and precarity for millions of people. But the cost of achieving urban resilience across the world dwarfs available public finance, both from development banks and governments themselves. Meanwhile, vast amounts of money on capital markets are searching for profitable investment opportunities. The World Bank is attempting to channel return-seeking investment into urban infrastructure in response to these challenges. But in order to harness this private finance, cities must be reformatted in investment friendly ways. In this paper, we chart the emergence of this discourse and associated practices within the World Bank. We call this rescaled and climateinflicted program of leveraged investments coupled with technical assistance Green Structural Adjustment. Drawing on policy documents, reports, and interviews with key staff, we examine programs that comprise Green Structural Adjustment to show how it aims to restructure local governments to capture new financial flows. Green Structural Adjustment reduces adaptation to a question of infrastructure finance and government capacity building, reinscribing both causes and effects of uneven development while creating spatial fixes for overaccumulated Northern capital in the Global South.
\end{abstract}

Keywords: Adaptation; Infrastructure; Development; Overaccumulation; Spatial Fix

Patrick Bigger, Lancaster Environment Centre, Lancaster University, Library Avenue, Bailrigg, LA1 4YQ, UK. p.bigger@lancaster.ac.uk.

Sophie Webber, School of Geosciences at the University of Sydney, Camperdown 2006, NSW, Australia. sophie.webber@sydney.edu.au. 


\section{Introduction}

Over the 1980s and 1990s, the World Bank ${ }^{1}$ and International Monetary Fund (IMF) restructured vast swathes of the global economy in response to the Third World Debt Crisis. The pair administered 196 structural adjustment programs (SAPs) in 64 countries in the 1980s, growing to 346 SAPs in 98 countries in the 1990s (Swaroop 2016) ${ }^{2}$. SAPs offered debt restructuring and fresh loans in exchange for the fulfillment of 'conditionalities': sweeping policy reforms that pried open markets in debtor countries while cutting state service provision, lowering environmental standards, and allowing interest rates to rise, subsidies to fall, and currencies to float. The results were, by and large, calamitous. The 1980s in particular came to be seen as a 'lost decade' for development as prosperity and wellbeing deteriorated across much of the Global South, trends often exacerbated in individual countries and regions by multiple rounds of structural adjustment (Hickel 2017). The era of structural adjustment formally came to an end in 2002 with the Bank transitioning to a more explicit focus on poverty alleviation and state capacity building, while the IMF's role remained macro-economic stability (Goldman 2005). In the Bank, the terminology of structural adjustment was phased out in favor of the gentlersounding 'Development Policy Lending' (Swaroop 2016, 6).

We argue that, as the impacts of climate change begin to bite in cities across the world, there is a new era of structural adjustment at hand: 'Green Structural Adjustment' (GSA). GSA mimics many aspects of $20^{\text {th }}$ century structural adjustment, but with three important variations. First, GSA is triggered not by unmanageable debt, as in the 1980s, but by a lack of access to debt across Global South cities coupled with an overabundance of stagnant Northern capital in search of returns. This is a key structural dynamic of GSA, as Bank programs aim to create opportunities to spatially-fix Northern capital mired in low yields in established markets and asset classes. The second difference is one of scale. The Bank is trying to create access to debt and investable projects, where they do not currently exist, allowing cities to borrow money to manage impending crises caused by rapid urbanization and climate change. Where SAPs targeted nation-states as the sites of policy reform and competent scale of borrowing, now municipalities are treated as the appropriate administrative unit. The third key difference is the explicit focus on climate, a departure from the environmentally calamitous lending of the Bank in the SAP era (Goldman, 2005).

We show that, through wide-ranging Bank interventions, GSA aims to reformat local governments across the Global South into reflections of Northern counterparts that have the capacity to borrow on international credit markets, use sophisticated environmental data to plan urban resilience projects, and manage contracts with global infrastructure companies to roll out public-private partnerships in the name of achieving 'resilience'. The conditionalities that comprise GSA do not come with the threat that, if unfulfilled, bailouts will be withheld, as in earlier SAPs. Instead, the Bank is the herald of investors, bearing the message that if city

\footnotetext{
${ }^{1}$ Which we refer to as 'the Bank' throughout.

2 SAPs were led by the IMF in the case of 'pure' balance of payments crises that required quick debt restructuring with conditionalities that foregrounded austerity, while World Bank lending was more directed to specific projects with conditionalities that turned on opening markets and relaxing other regulations. The two forms of conditionality were often imposed together as part of joint lending packages (Colgan, 2002).
} 
governments are not reformed in investment-friendly ways, those cities will continue to be cut off from access to the $\$ 106$ trillion $^{3}$ swirling on global capital markets (World Bank 2015b, 57). Access to private capital is portrayed as critical not only for development, but for social, economic, and environmental resilience in the face of climate change, the cost of which far exceeds existing, or even imaginable, public funds. Where SAPs achieved spectacular de- and reregulation and asset stripping (Corbridge, 1994), GSA operates through manifold policy-tweaks that seek to cultivate investable, managerial cities, empowering Northern experts to guide municipal policy. The conditionalities that comprise GSA seek to render cities investable through reforms in municipal governance, the production and analysis of environmental data, and various forms of administrative capacity building. The Bank's supposedly post-ideological pragmatism, born of its rebranding to 'solutions bank' in the early 2010s (Denning 2012), turns on impotent national and supranational action on climate and the supposed omnipotence of financiers who will only come to the rescue of vulnerable cities if the exacting needs of investors for project preparation, data and returns are met.

In this paper we demonstrate the character, scope and extent of GSA, focusing on how it is driven by, and unfolds within, the Bank. We argue that GSA is not, directly, about the financialization of resilience or infrastructure; rather, it is a policy architecture seeking to produce cities as investment sites, with investors (and the Bank) the default experts for achieving urban resilience. ${ }^{4}$ In tracing the emergence of GSA, we bring together several geographical literatures, including on development finance, the financialization of environmental and social goods and services, and critical assessments of resilience. We casually tie GSA to SAPs, chart continuities and ruptures between the two paradigms, and signal the structurally coherent, if geographically dispersed, nature of GSA. The structural - and uneven geographical - stakes of this argument are that the Bank, in concert with other powerful actors in the global development and financial industries, is facilitating transformations to allow cities in the Global South to sop up excess capital from the Global North. It is a preparatory program for creating 'surfaces' to which spatially-fixing capital might adhere, producing new geographies of rent extraction through regulatory reform and co-financing to meet resilience qua infrastructure needs (Harvey, 1982; Mezzadra and Neilson, 2019).

The scope of GSA is large and growing. In a 2016 interview, a World Bank Urban Resilience Specialist claimed to have worked on 77 urban resilience projects across 40 countries, involving almost $\$ 10$ billion; ${ }^{5}$ the Bank now aims to facilitate $\$ 500$ billion into urban resilience in 500 cities (IEG 2019). To illustrate our argument, we draw on examples from across cities that exemplify how different components of GSA are being implemented. We selected cases across world regions and income levels to demonstrate that, despite specific contexts, GSA is a widespread phenomenon with structured coherence. Our arguments are based on an initial review of hundreds of World Bank and associated reports, webinars, webpages, and project documents, followed by a thorough review of more than 90 World Bank reports and technical documents, supplemented with data from project documents and Country Policy Frameworks. The second author conducted fieldwork with World Bank officials in Jakarta and Washington D.C. about the growing importance of environmental and financial innovation to achieving urban

\footnotetext{
${ }^{3}$ All monetary sums are in USD except where noted otherwise.

${ }^{4}$ Thanks to generous reviewers for providing this more forceful wording.

${ }^{5}$ Interview, World Bank Urban Resilience Specialist, Washington DC, September 2016
} 
resilience between 2016 to 2019 , including ten interviews that directly inform the analysis here. ${ }^{6}$ Where we draw on information learned through interviews, we note the informant's job title, and the date and location of the interview. Using our database of Bank documents and interview transcripts, we inductively analyzed this data to identify the discourses, policies and practices that comprise the Bank's agenda. In order to trace and outline GSA, our analysis relies upon secondary sources and interview data from technical experts; further research will be required to chart how GSA manifests - socially, environmentally, and economically - in specific cities over the years to come. Similarly, our argument is constrained to the Bank. It is certainly not the only pertinent actor in $\mathrm{GSA}^{7}$, but the Bank's geographical, financial, and technical reach warrants particular attention.

The paper proceeds in four sections. In the next section, we chart the shift from SAPs to GSA by way of pertinent geographical literatures: the policies and practices driving contemporary forms of development policy writ large, the financialization of nature and infrastructure, and critical assessments of resilience. Then, we explore how these ideological commitments are mobilized as GSA in a new era of 'There Is No Alternative', one in which the inescapable conditions are not roll-back neoliberalization, but rendering cities investable in a high-liquidity, low return world. In the third section, we locate the constituent practices of GSA in two exemplary initiatives, the City Resilience Program and the City Creditworthiness Initiative. We also outline the financial mechanisms that green conditionalities are meant to facilitate, from 'vanilla' Development Policy Lending to more exotic, private sector-oriented pathways. We conclude by locating green conditionalities in the world of climate-financial entanglements, where financiers have, in the minds of elites, become the only credible actors to prevent socioenvironmental catastrophe, then identify specific research needed to interpret spatially and political-economically divergent outcomes from GSA interventions across the world.

\section{From SAPs to GSA}

There is a fairly direct connection between $20^{\text {th }}$ Century SAPs and contemporary GSA. The phrase 'Washington Consensus' was offered by Williamson in the late 1980s to refer to a collection of policies that were "common sensical" for facilitating development, including deregulation and liberalization of trade, privatization of state enterprises, and enforcing private property regimes (Williamson 2000). The conditionalities of structural adjustment were geared towards imposing this ideological position on insolvent countries. As the debt crises that precipitated SAPs were framed as a balance of payments problem, reforms aimed to lower trade barriers to restructure rural economies and accelerate earnings from agricultural and primary materials exports while reducing imports (e.g. Samatar 1993). However, the implementation of the Washington Consensus was considerably more diverse across countries than a singular, antistatist focus on liberalization, privatization, and economic growth (Naim 2000), much like GSA today.

\footnotetext{
${ }^{6}$ Two interviews with Urban Resilience Specialists are particularly pertinent for our argument and so are referenced throughout the analysis.

${ }^{7}$ Others include philanthropies such as the Rockefeller Foundation, global consulting firms such as Arup and AECOM (Leitner et al 2018; Webber et al Forthcoming), investors and other financial actors such as ratings agencies, and city and national governments
} 
In the wake of the profound failures of the Washington Consensus, critics have diagnosed several new development paradigms. A post-Washington Consensus of the early 2000s criticized the market-led, globalizing focus of its predecessor (Naim 2000; Stiglitz 2002), instead focusing on good governance, democracy and institutions, an increased role for neo-Keynesian states and government regulation, and poverty reduction, empowerment and social capital (Fine 1999; Sheppard and Leitner 2010) even while neoliberal prescriptions remained central to development programming. ${ }^{8}$ Part of this shift stemmed from internal criticisms of Washington Consensus programming as New Institutional Economics gained traction in the development industry and the failures of Structural Adjustment became clear (Best 2014). More recently, development commentators declare the post-Washington Consensus over; Mitchell and Sparke (2016) diagnose a shift towards a New Washington Consensus (NWC). The hegemonic, if contingent, New Washington Consensus is an interplay between micro-market transformations of communities and individuals to overcome macro-market failure. NWC is less "top-down structural adjustment" and more "bottom-up innovations in market-making by new market subjects" (Mitchell and Sparke 2016, 732) with an emphasis on rendering development investable by private sector financiers (Mawdsley 2018a). Similarly, Gabor (2019) diagnoses the consolidation of the 'Wall Street Consensus' that, "re-imagines international development interventions as opportunities for global finance" (25). For the Bank ${ }^{9}$, these consensuses are coarticulated as a progressive restructuring from lead lender to countries perceived as bad risks into a 'creature of Wall Street' (Thomas 2018); direct development assistance is out, blended finance to facilitate win-win-win investments for institutional investors that unleash entrepreneurial development subjects is in. This manifests across the Bank's portfolio, from Social Bonds that finance women entrepreneurs to emergency financing facilities for refugee host countries. These programs, along with others (especially those that comprise GSA), aim to use Bank money as a catalyst to prompt private sector investment. As former Director General Kim put it, the bank has moved away from direct lending to undertake activities to 'systemically derisk' not just projects, but entire countries, (Kim 2017; Stein and Sridhar 2017).

While any substantive institutional reorientation, like GSA, will have a variety of impetuses, we argue that many of the policy, economic, and even environmental conditions produced through $20^{\text {th }}$ century structural adjustment are a casual factor in the conditions that GSA targets, from underinvestment in public goods to structural imbalances in global capital accumulation. In Mexico for example, state-owned infrastructure was a significant component of its debt in 1982, and was, therefore, a target of conditionalities in the wake of the state's technical default that kicked off the broader debt crisis. This included expansive hydraulic infrastructure that watered Mexican crops, produced hydroelectricity, and piped water to rapidly growing and increasingly thirsty Mexico City. One of the first reforms imposed in the wake of the 1983 bailout was the transfer of responsibility for water provision from the federal government to municipalities, including Mexico City (Salazar 2007). This took significant maintenance and operational costs off the national balance sheet, began a nationwide process of decentralization, and laid the groundwork for escalating rounds of commercialization of water (Wilder and Romero-Lankao

\footnotetext{
8 The relative importance of 'good governance' versus structural adjustment is up for debate (including whether they constitute distinct ideologies or programs), as are the normative implications of this shift (see Sheppard and Leitner 2010).

${ }^{9}$ The IMF has maintained the logics and practices of Structural Adjustment in the 'post' Structural Adjustment era, perhaps even accelerating in the wake of the 2008 financial crisis, despite claims to have transitioned away from highly prescriptive austerity measures as a condition for rescue packages (Kentikelenis et. al, 2016)
} 
2006). Since then, transnational companies have played an increasing role in water provision for Mexico City, with associated underinvestment, deterioration, and rent seeking (Adler 2015; Wilder and Romero-Lankao 2006). Seeking 'sustainable water solutions' to a worsening crisis, Mexico City has now issued three green bonds, two of which have directly funded more commercialized water infrastructure (Arce Lozano and Davalos 2019). Mexico City thus reflects many of the qualities that the Bank hopes to impart in cities through GSA, including devolved borrowing capacity, a high credit rating backed by sovereign guarantee, access to, and sophisticated use of, environmental data for planning projects, and fully developed national and local public-private partnership regulations for infrastructure. Becoming investable was helped along by Structural Adjustment and other contentious federal economic policy adjustments (e.g. NAFTA, see Vasquez 2015), alongside municipal and development actors, including the Bank. The Bank estimates that by 2030 Mexico City will have almost $\$ 40$ billion in privately investable infrastructure projects, facilitated by Mexico's 2016 national PPP law and capacity building in departments across municipal government (IFC 2018). GSA aims replicate this model across Southern cities, often as a response to problems caused or exacerbated by $20^{\text {th }}$ Century SAPs.

More generally across the Global South, common conditionalities of $20^{\text {th }}$ century SAPs, including 'rationalizing' agriculture and decreasing spending on state services, contributed to population flows into cities and growth in precarious urban communities (Davis 2006). World Bank economists subsequently puzzled over 'urbanization without growth' (Fay and Opal 1999). Meanwhile, reduced trade and investment barriers instituted through SAPs assisted growth in hydrocarbons and raw material extraction and export in countries possessing such resources, turbocharging rich world consumption and associated greenhouse gas emissions. Structural adjustment-facilitated extractivism simultaneously degraded local environmental conditions and globally increased exposure to environmental risks brought on by greenhouse gas emissions associated with the acceleration of industrial production and distribution of goods manufactured from those materials (Hickel 2017). In the decades since structural adjustment, the volume of investable money has swelled such that financial markets are bloated with liquidity in search of yields. Through GSA, cities must now compete, with World Bank assistance, for this funding on international markets if they are to build resilience to deteriorating, unpredictable environmental conditions.

One key aspect of both the New Washington Consensus and Wall Street Consensus is an expansive rhetoric that private capital is the only solution to a dizzying variety of developmental, social, and environmental issues. This outlook goes under monikers like 'impact investing' (Rosenman 2019) and 'philanthrocapitalism' (Mediavilla and Garcia-Arias 2019). The conditions, ideas, and practices that structure these interventions all turn on faith in the "transformative power of markets" coupled with the waning power of states to effectively deal with social (Lake 2015), environmental (Schmidt and Matthews 2018), and development (Mawdsley 2018b) issues alongside the increasing concentration of capital with the global investor class. Geographers have tended to describe these interventions as the 'financialization of X' (Christophers 2015) - a formula that turns on how various bits of the world are made to perform as bankable projects, and what those projects do.

In this article, we are not concerned with the performance of bankable projects per se - whether or not they achieve a measure of urban resilience or produce new 'financialized' natures, for instance. Instead, we focus on the sundry interlocking programs, facilities, discourses, and 
practices that are meant to foster the conditions of bankability, perhaps the preconditions for financialization of urban adaptation in cities not currently legible to investors. That is, we ask: how are cities being rendered investable to achieve the World Bank's version of urban resilience? GSA does not necessarily produce any new financial mechanisms, nor new concerns on the part of financiers, but instead entails new governance techniques for opening spaces to finance in the name of resilience - a spatial fix for finance. Moreover, the definition of urban resilience matters very little: ${ }^{10}$ GSA is not overly prescriptive about what urban resilience and its associated infrastructure might look like, but is more concerned with how, and by whom, projects are to be financed. The critical resilience literature has debated the precise, multiple, or empty definitions of resilience (Braun 2014), the family resemblances between resilience and neoliberalism or individualism/entrepreneurialism (Anderson 2015, Long and Rice 2019), and the forms of environmental governance that this facilitates (Grove 2018). The claim we make here, however, is not that urban resilience is financialization or has been financialized, but that GSA sets up urban resilience, whatever it might be, as dependent on private financial flows which turns on reformatting city governments. Accordingly, if the right kinds of reforms are enacted in cities in need of urban resilience, then familiar financial mechanisms - public-private partnerships (Whiteside 2019), municipal borrowing through labeled green bonds (Bigger and Millington 2019), or land-value capture ${ }^{11}$ (Weber 2010) to name a few - are the conduit by which investments can flow in, rents can flow out, and conditions amenable to resilience can be achieved (see O'Neill 2019). GSA, then, is about spatial fixing achieved through supranational initiatives as a response to overaccumulation, as new municipal capacities to absorb footloose capital aim to, "[fix] investments spatially, embedding them in the land, to create an entirely new landscape... for capital accumulation," (Harvey, 2001, p.27)

\section{The productive discourse of development through urban resilience}

At the heart of GSA is a series of connections between urbanization, climate change and infrastructure in cities of the Global South and the types of interventions this confluence demands. The Bank diagnoses that rapid urbanization and climate change are causing costly infrastructural crises in cities. On the one hand, the costs of disasters in cities of the Global South are large and are growing. The Bank estimates that current average annual losses from disaster are more than $\$ 300$ billion a year, anticipated to grow to $\$ 415$ billion by 2030 , and by 2050 losses in coastal cities from sea level rise alone could top $\$ 1$ trillion annually (World Bank 2015b). Because cities are "hubs of economic" activity, losses associated with climate change threaten to "reverse hard-won development goals" (World Bank 2015b, 43; 13). Maintaining development gains in cities depends on access to infrastructure; financing infrastructure that is resilient to shocks and stresses is, therefore "one of the most urgent challenges in development" (World Bank 2015b, 43). As temperature increases, extreme weather events become more regular, and sea level rises, damage to urban water, energy, and transport infrastructure will

\footnotetext{
${ }^{10}$ In its flagship report on financing urban resilience the World Bank defines urban resilience as "the ability of a system, entity, community or person to adapt to a variety of changing conditions and to withstand shocks while still maintaining essential functions" (World Bank 2015b, 19).

${ }^{11}$ Land-value capture is a form of financing that attempts to capture the value created from public investments in land. In the case of infrastructure financing for urban resilience, the World Bank hypothesises that land values will increase due to population growth, economic development, public investment in infrastructure, land use changes, and landowner investments, and that these increases can be monetized ('captured') through various tools (i.e. taxes, fees, incentives) to finance resilient infrastructure (City Resilience Program, n.d.).
} 
degrade the services these systems provide (World Bank 2018c). As a result, both the capital and operating costs of infrastructural investments are expected to increase because of climate change, especially if proactive investments and strategic planning are not pursued (Rozenberg and Fay 2019).

The Bank narrative for justifying GSA unfolds as follows. Investing in urban resilience, and particularly resilient infrastructure, will abate losses from climate change and enhance development outcomes. A World Bank Urban Resilience Specialist noted that "the estimate is $\$ 400$ billion to $\$ 1.1$ trillion a year is needed just to make infrastructure climate and disaster proof" ${ }^{\prime 2}$; and then there are the additional costs of new infrastructures in rapidly urbanizing cities. Indeed, infrastructure spending in low and middle income countries is anticipated to be between two and eight per cent of GDP by 2030 (Rozenberg and Fay 2019), while up to 80\% of losses from climate disaster could be avoided through investments in resilient infrastructure (World Bank 2015b). The Bank claims that an investment of \$6 billion in a "resilience package" that includes financial measures ranging from the individual to national scale, could generate more than $\$ 36$ billion in savings (2015b). Infrastructure is projected to be particularly rewarding for cities as it increases economic growth and productivity: a 1\% increase in infrastructure spending would generate $1.5 \%$ GDP growth over four years, and well planned and executed investments can be even more profitable (World Bank 2015b).

But, the volume of funding needed for urban resilience dictates that public finance will be insufficient. As the Urban Resilience Specialist describes, the key problem for urban resilience is that "the money is not flowing"13. Given the trillion-dollar price tag, public sector financing either locally through measures such as taxation or multilaterally through Official Development Assistance (ODA) - will always come up short. As a key document makes clear: "public investment alone, even when combined with ODA, is inadequate" (World Bank 2015b, 54). Thus, the Bank's role is not simply as a lender for urban infrastructure with a bit of policy recommendation, but instead actively seeks to facilitate private investment by identifying "what are the obstacles and what are some of the measures that can overcome them?" And, "So where does the World Bank fit in, ... how can we lead more?"14.

Thankfully for vulnerable cities, the Bank finds that the world is awash with private capital ripe for investment in urban resilience. Indeed, "investment capital seems to be abundant" and investors and insurers have expressed a willingness to invest in a "broader universe of investment opportunities... [including] illiquid infrastructure assets in frontier emerging markets as a means of enhancing otherwise poor returns" (World Bank 2015b, 57; 58). It is now the role of the World Bank and other multilateral development actors to use their own investments, aid, and grant funding "in innovative ways to catalyze trillions" (World Bank 2018b, 1, see also Mawdsely, 2018a). Because, although there is abundant investment capital, "right now less than $2 \%$ gets invested in urban infrastructure. So, these are pension funds, sovereign wealth funds, mutual funds, and they're out there, they're looking for reasonable returns, in a very low return market right now. So, we think there's an opportunity to tap some of that in terms of leveraging and co-financing" $"$. As this quote reflects, the fixed income investors who might be attracted to

\footnotetext{
12 Interview, World Bank Urban Resilience Specialist, Washington DC, September 2016

${ }^{13}$ Interview, World Bank Urban Resilience Specialist, Washington DC, September 2016

14 Interview, World Bank Urban Resilience Specialist, Washington DC, September 2016

${ }^{15}$ Interview, World Bank Urban Resilience Specialist, Washington DC, November 2016
} 
high, stable return investments to pay for rapidly rising pension costs across the Global North (Clark 2000) are risk-averse and require generous subsidies and risk off-takes to invest, even in the face of an overaccumulation crisis that is marked by low yields in 'conventional' asset classes and markets. The Bank is developing programmatic initiatives that we group under the heading of GSA to make this form of investment less risky, more predictable, and more lucrative for Global North investors to own the infrastructure that comes to represent the survivability of Southern cities. The policy reforms and capital mobilization enabled by GSA produces cities as outlets for overaccumulated Northern capital, in line with other shifts to private-sector investability in development (Mawdsley, 2018b). The Bank's role is to facilitate the export of regulatory frameworks and financial mechanisms far and wide, looking beyond "the investment in IBRD projects... [to] the guarantees, the stimulation of the insurance market, a whole range of financial products and the capacity to translate an assessment of a situation into a bankable investment" 16 .

And yet, it is not simply the case that cities 'just need access' to this private capital because "many of these cities are constrained by other factors that reduce their access to credit" for urban resilience (World Bank 2015b, 15). These constraints fall in two key domains: financial and strategic governance on the one hand, and environmental data, measurement and monitoring on the other. The Bank finds that Global South cities have a variety of governance lacks that prevent them from accessing private capital (World Bank 2015b). Most cities lack the ability to strategically plan a pipeline of financeable investments and they cannot plan, in detail, urban infrastructure projects: "One of the biggest obstacles to money flowing into cities, is the lack of financeable projects, cities just don't - in the developing world - know how to put together investments" 17 , or cities struggle to identify their goals for urban resilience and "translate that into bankable investments" 18 . Cities do not have sufficient urban planning or strategic risk planning capabilities, local project design implementation and assessment skills, or abilities to create and enforce regulations such as building codes and land use plans. Regulatory clarity is also needed, because even though Bank ideology dictates that markets can ensure the efficient delivery and operation of urban infrastructures, governments need to provide regulatory structure and institutions. But, these need to be regulations and institutions of a very specific kind, particularly suited to remove barriers to private sector investments: "capital inflow controls, tax policies, labor policies and inconsistent tariff policies can build complexity into a transaction and reduce the attractiveness of an investment" (World Bank 2015b, 47). Governance and regulation also may need to be rescaled so that city governments have the authority to build infrastructure, have control over zoning and land use, and have developed regulatory capacity in order to improve transparency, accountability and service delivery. The desirable municipality here lines up neatly with 'model' cities that have active PPP portfolios enabling private control of public goods, as in Mexico City.

Cities also are constrained by their financial management and governance practices. From the Bank's perspective, "many cities are not well managed financially, and are prone to risks of corruption" ". Municipal governments may have limited skills in fiscal management, capital investment planning and project preparation. As a result, cities are not creditworthy and cannot

\footnotetext{
${ }^{16}$ Interview, World Bank Urban Resilience Specialist, Washington DC, September 2016

17 Interview, World Bank Urban Resilience Specialist, Washington DC, September 2016

18 Interview, World Bank Urban Resilience Specialist, Washington DC, November 2016

19 Interview, World Bank Urban Resilience Specialist, Washington DC, November 2016
} 
secure access to capital markets (World Bank 2018c). This is a critical issue for attracting the volume of investment envisioned by the Bank because of the symbolic importance and performativity of credit ratings (Paudyn, 2013). Capital constraints also arise from the inability for cities "to generate own-source revenues" (World Bank 2015b, 53). Instead, cities often rely on unpredictable transfers from central states for operating budgets, and cannot raise money through mechanisms like land taxes, or access capital markets without new legal frameworks or sovereign guarantees. Indeed, the Bank recognizes that as the expectations of city governments to provide urban resilience to citizens have increased, this has not been met with sufficient abilities to fund raise. These fiscal management lacks revolve around "the general lack of capacity within local government" - including a limited capacity in tax assessment, revenue collection, and enforcement (World Bank 2018c, 13). These governance challenges "send, sort of, dangerous signals to the market" 20 .

In addition to strategic and financial management, cities are limited by a lack of environmental data for planning urban resilience. As is recognized by both programmers and critics of carbon markets - and repurposed here for urban resilience - measurement is vital to governance and financial management, because "you can't value what you can't measure" (Gifford 2020). Accordingly, in order to attract investors, cities need greater access to data about environmental risks, and the ability to work data into their strategic planning. Environmental and climatic data are integral to this endeavor - this includes the production of climate information and services, and ensuring that data are accessible to potential users (World Bank 2019b). Beyond climate data, there is a need to improve private sector confidence through the creation of benchmarked data for measuring resilience (World Bank 2019b). The Bank is busy creating new ratings, standards, and metrics systems that will "create incentives for, and improve the tracing of, global progress on adaptation and resilience" (World Bank 2019b, 5). This information is important for attracting private capital, particularly so-called impact investors because without ratings and benchmarks, there are no market prices or expectations of risk and return (World Bank 2015b). Currently, "markets lack uniform guidance on what constitutes a climate resilient investment" (World Bank 2019b, 16). Moreover, the Bank and others have determined that cities need to monetize and capture 'resilience dividends' (Rodin 2014). With investments in data and measurement of resilience, the World Bank anticipates "potentially unlock[ing] significant amounts of capital" (World Bank 2015b, 50). Overcoming urban governance and environmentalclimatic measurement challenges is central to the emerging World Bank agenda on urban resilience. The Bank aims to "help cities overcome some of these obstacles" 21 through technical assistance programs and specialized financing facilities, magnifying the power of local and transnational technocrats.

Building up measurement practices are part and parcel of using Bank resources to leverage private investment through a variety of low-cost financial mechanisms to de-risk private investment and signal non-monetary benefits that accrue from investments in resilience. Regarding urban resilience, the Bank records high leveraging ratios: across their climate investments, all Multilateral Development Banks claim to leverage three dollars of private finance for each dollar spent. This is even greater for the World Bank, as every dollar mobilized through its on-lent bonds results in five dollars of non-World Bank lending (World Bank, 2015). The repetition of these ratios reflects austerity ideology's demand that 'value for money' be the

${ }^{20}$ Interview, World Bank Urban Resilience Specialist, Washington DC, November 2016

${ }^{21}$ Interview, World Bank Urban Resilience Specialist, Washington DC, November 2016 
guiding principal of all public spending. In the Bank's Pilot Program for Climate Resilience, \$203 million in water, energy, and transport investments has "leveraged \$661 million in cofinancing from government and private sources" (World Bank 2018c, 34). In the urban register, the Bank's City Resilience Program aims to leverage its US $\$ 4$ billion in multilateral financing to "crowd-in" \$4 billion in private capital across 20 cities (World Bank 2015b). Leveraging revolves around strategic co-financing, but also guarantees and other risk management instruments, using the World Bank balance sheet, credit rating and technical assistance to incentivize private capital while leaving the "investing, driving innovation, and improving delivery" to the private sector (World Bank 2018b, 1). The World Bank is to be "a facilitator of capital" (World Bank 2018b, 3) leaving decisions about which urban resilience investments go ahead - likely those with highest and most secure returns rather than the pure public goods - and the form of the projects themselves to investors, as we now explore in specific examples of GSA programs.

\section{Facilities and programs of GSA}

While the World Bank's version of urban resilience is being 'mainstreamed' into its overarching practices more broadly (World Bank 2019b), a handful of Bank initiatives exemplify GSA and the ways that it is becoming an organizing logic of and for capital. GSA as discourse and practice is not unique to the World Bank, or even the Bretton Woods institutions, but the Bank is the key node in the GSA ecosystem. With Bank leadership, the project is made actionable through a vast web of initiatives conducted in partnership with other institutions, including other development finance institutions, advocacy organizations, industry groups, bilateral aid agencies, think tanks, and philanthropies, from the UK Department for International Development to the Rockefeller Foundation. In this section, we review two Bank programs through which GSA is operationalized: the City Resilience Program and the City Creditworthiness Initiative.

\section{The City Resilience Program}

The World Bank's flagship program for rendering cities investable to achieve urban resilience is the City Resilience Program (CRP). CRP was established in 2017 as part of a push to "make urban resilience a formal product line, so that it can become something that we [the Bank] do as business as usual" "22. The goal of the CRP is to operate as "the investment banker to cities, helping to boost the bankability of projects and catalyze the flow of financial resources to emerging markets" (World Bank 2019a). But, these urban resilience projects need to be "better and bigger", with ambition in technical design and financial scope (World Bank 2019a). The CRP has two key programs for cities which address "both sides of the challenge" (World Bank 2018a): the Resilience Enhancement Track and the Capital Mobilization Track. Both Tracks are designed to facilitate investments specifically in urban resilience through technical (Resilience Enhancement Track) and financial (Capital Mobilization Track) assistance. Although the Tracks run independently cities often participate in both, either simultaneously or consecutively. Cities in the Resilience Enhancement Track undertake a broad scan to highlight resilience challenges based on geospatial data and thereby enable a conversation between cities and technical assistance at the Bank to "package, prioritize and design resilience enhancing investments" (GFDRR, 2019). Through this Track, cities design investments and strategic investment plans, ensuring that climate and disaster risks are embedded in decision-making. Bringing technical

\footnotetext{
${ }^{22}$ Interview, World Bank Urban Resilience Specialist, Washington DC, November 2016
} 
assistance from across its 'diverse ecosystem', the Bank hopes to shift urban resilience from a sectoral concern to a strategic and integrated priority. In the Capital Mobilization Track, cities begin not by highlighting resilience challenges, but by diagnosing the ability to mobilize private capital; to date, 52 cities have formally participated in this assessment. Cities can then work with financial advisors (including through a 'shark tank' activity for city officials to pitch to investors) to ensure their enabling environment is amenable and their fiscal strategies are sound - with a focus on reviewing regulatory 'roadblocks', project valuation, and financial modelling. Since it was initiated, 90 cities have participated in the CRP, including 35 that joined in 2019. Five of these cities are now working "towards private capital transactions" and 16, from Abidjan to Tashkent, have received training for deployment of "geospatial solutions" (World Bank 2019a; GDFRR, n.d.).

Through the two Tracks, the CRP hopes to 'empower' cities to program urban resilience investments - but the pursuit of private capital is paramount. In a survey about their involvement in CRP workshops, World Bank staff recognized that scaling and operationalizing private investments in urban resilience remained a challenge, but they also reiterated that the CRP process is essential for starting conversations "with urban counterparts not used to engaging with the finance masters on capital mobilization strategies", helps "nudge the mindset towards ... inviting private participations where possible" and is a useful tool "in pushing the PPP agenda" (City Resilience Program n.d.). The key financial tools that the CRP facilitates are PPPs - for either service delivery of investment and financing - and Land Value Capture (LVC), with direct lending to governments also considered, although less likely (City Resilience Program, n.d.).

Consider the case of Can Tho City, Vietnam. Can Tho City is the "economic engine" of the Mekong Delta Region in Vietnam, and faces challenges from rapid urbanization, climate change and associated flooding, and a lack of infrastructure to serve the city's population - in short, the suite of issues to which GSA is calibrated (World Bank 2015a). In 2014, Can Tho was the first city to undertake the City Strength Diagnostic Methodology - a process which involved conversations between city officials, key city stakeholders, and Bank staff in Washington and Hanoi to identify stresses and investment priorities to address these challenges (CityStrength 2014). The tool is a precursor to the two CRP Tracks. The City Strength assessment identified that in order to address the twin risks of flooding and rapid urbanization, the city needed to manage urban growth by encouraging building in less flood-prone areas and pursuing policychange and investments in flood mitigation, and transport and sanitation infrastructure. The resulting \$250 million Can Tho Urban Development and Resilience project aims to do exactly these things - combining infrastructural investments in engineering solutions to flooding, the construction of transport linkages, and policy reform (World Bank 2015a). Through the City Strength tool and its findings, "the government decided to change the focus of the project to incorporate aspects of urban resilience"23. The city's engagement with the Bank's technical assistance on urban resilience has shifted urban governance priorities to making resilience investable.

Since this initial engagement, the Bank and Can Tho City have continued to pursue investments in urban resilience, and they city has participated in the City Resilience Program on the Capital Mobilization Track. Their Rapid Capital Assessment, through which the World Bank assesses the city's potential for engaging PPPs and using LVC, is particularly illuminating of the kinds of

${ }^{23}$ Interview, World Bank Urban Resilience Specialist, Washington DC, September 2016 
policy reforms that comprise GSA (City Resilience Program, n.d.). There have been several PPPs in Vietnam, particularly in the electricity sector, and now PPPs are planned for transportation, water and sanitation. However, in order to encourage more PPPs, particularly at the sub-national level, the World Bank has been overseeing regulatory changes to enhance "structuring and management" of PPPs (City Resilience Program, n.d., 36). The Bank has also facilitated a city scale 'Infrastructure Financing Facility' and 'Local Development Infrastructure Funds', both of which will fund municipal infrastructure investments. These facilities will act as a "second tier lender encouraging first tier lenders (commercial banks)" (City Resilience Program, n.d., 68), reflecting the leveraging strategy of GSA as city officials starved for infrastructure finance in the face of socio-environmental change search for investment. In terms of LVC, the Bank identifies the existing, paper cadaster as an impediment resulting in issues around "local market transparency" (City Resilience Program, n.d., 40). Although they find a willingness from investors and city officials to trade land for developer rights in infrastructure, the Bank suggests that local and national changes are needed to "organize and efficiently structure a process of disposition of development rights" (City Resilience Program, n.d., 43).

The CRP, in other words, is working across city and national scales to transform policy environments and provide technical and geospatial solutions (i.e. around the cadaster) to ease implementation of PPPs, LVCs, and municipal debt instruments, as well as supporting urban governance transformations around urban planning and coordination (World Bank, 2018a). While SAPs of the 1980s and 90s were more violently imposed, the shifts that comprise GSA reflect a persuasive, disciplinary approach. GSA promises new financial flows to solve urban crises within an overarching discourse of global austerity, fiscal rectitude, the power of returnseeking capital, and the devastation promised by climate change that public funds will be unable to avert. $20^{\text {th }}$ century SAPs contributed to the normalization of policy that, across scales, has make thinking outside of the austerity-box significantly more difficult; GSA is the expression of these same logics pursued by other means and in response to the conditions produced, in part, through SAPs.

Speculative attempts to reformat city governance in pursuit of investments in urban resilience are also evident in Jakarta, Indonesia, which has participated in phase one of both Tracks of the CRP. The Jakarta Urban Flood Mitigation Project aimed to regularize Jakarta's many canals to prevent urban flooding, including through drainage, dredging, new dam systems, but also by evicting canal-side Kampung communities (Leitner, Sheppard, and Colven 2017). The Project began with "invest[ing] in information, on data... the whole spatial infrastructure... [so as to be] able to build the proper analysis." 24 This data and monitoring lead to systematic physical risk assessments. But governance transformations across the watershed were also identified by project personnel as integral to flood management - particularly creating better connections across local governments, and enabling national and provincial involvement to better produce, implement, and monitor multi-sector and multi-scalar land use change regulations and building codes. Project personnel also identified that urban governance transformations were integral for LVC for capital works to prevent flooding. For instance, dredging for flood mitigation produces sediment, which in turn can be used to create land. If "you value that with the value of land for ... apartments going in there, the city government can actually pay the entire loan... It's just

\footnotetext{
${ }^{24}$ Interview, World Bank Disaster Risk Specialist, Jakarta, August 2016
} 
simple economics. Jakarta... anything they do, if they do it right, it can pay [for] itself. ... But the systems to capture that rent is not there." ${ }^{25}$ This quote demonstrates the Bank's linear assumption that improved regulations to allow LVC, along with other mechanisms, will subsidize the costs of flood mitigation, creating the conditions for bankable projects and bankable cities that sum to urban resilience and the mainstreaming of Global South municipal infrastructure as an asset class.

\section{City Creditworthiness Initiative}

The City Creditworthiness Initiative (CCI) is the second exemplary program for understanding GSA. Per the CCI website, "[h] elping local and municipal governments access financing has become an integral part of the World Bank's sustainable urban development strategy" (World Bank, n.d.), aiming to bring cities into regional, and eventually international, capital markets to fund resilient infrastructure. The CCI is broken into two main components: City Creditworthiness Academies (Academies) and City Creditworthiness Implementation Programs. Launched in 2013, the CCI builds on previous Bank work, especially an experiment building creditworthiness in Lima. The experiment was deemed successful when Lima was assessed at Ba1 by Moody's, after which the city issued PEN593 million in debt to refinance local bank debt and undertake infrastructure projects (Moody's Investor Services 2010; 2013). The Academies are training courses for bureaucrats to assess their city's capacity to issue debt on regional or international capital markets, while Implementation Programs are long-term, in-depth, technical assistance programs to rectify impediments to creditworthiness that were identified at the Academies. The Bank's estimated return-on-investment is eye-popping: the Bank claims a multiplier of $\$ 100$ of external investment in urban resilience for every $\$ 1$ in technical assistance (Podevin 2018). While not all of that 100:1 multiplier will be sourced from return seeking private capital, the Bank clearly sees potential for this version of technical assistance to make cities investable in the name of resilience.

The first Creditworthiness Academy was held in Nairobi in 2013 and since then the Bank has hosted at least 8 Academies designed to build capacity of officials from more than 300 cities in 30 countries. Ultimately the CCI aims to reach cities across 60 countries, which will subsequently diffuse to up to 2,000 cities through in-country best practice sharing in a bid to bridge the "creditworthiness gap", after which cities can begin to close the "infrastructure gap" (Podevin 2018, 223). The achievement of a credit score - recognized internationally or regionally, or even a 'shadow score' gained through a less rigorous assessment to enable local bank lending - is a major step toward accessing debt for urban resilience, but one that poses significant challenges for many cities. As one Bank staffer put it:

"Some people have said, well, can't you change your articles of incorporation to allow for this direct lending to cities, and our response is, well, we could but the market is very small, because a city has to be creditworthy in order to borrow directly from the World Bank, or from any kind of Bank.... So, I think the challenge is really not necessarily for us to change our behavior, but to help cities to be able to access capital markets by becoming creditworthy" 26

\footnotetext{
${ }^{25}$ Interview, World Bank Disaster Risk Specialist, Jakarta, August 2016

${ }^{26}$ Interview, World Bank Urban Resilience Specialist, Washington DC, November 2016
} 
Here, the Bank specialist points to one of the key motivations and modalities of GSA, in that Bank operations are still pitched primarily at states, not cities. Around 4\% of the 500 largest cities in the Global South are considered internationally creditworthy; that number grows to around $20 \%$ of cities if the scale of creditworthiness is regional (World Bank, n.d.). This means that 400 of the world's largest cities do not have access to debt, seen by the Bank as both a problem to be rectified through technical assistance and as an opportunity for stagnant capital. Providing technical assistance to municipal governments rescales the modalities of 'Maximizing Finance for Development' to the urban, without need to alter the Bank's charter (Mawdsely, 2018a).

Academies are not only about collating data that can flow into credit score applications, although the implementation of standardized accountancy practices is the first step in becoming debtready. Advice is offered, along with examples of best practices from around the world, to improve municipal fiscal outlooks. These governance recommendations tend to be well-worn tropes regarding transparency, reducing corruption, improvements in revenue collection, reductions in service provision, and building all manner of capacities to outsource municipal governance functions and infrastructure provision. For example, CCI technical assistance and funding allowed Arusha, Tanzania, to use geotagging and GIS mapping to identify small businesses that had avoided taxation, thereby improving revenue collection. The aim was not simply to collect tax for improved municipal services, but as a waypoint toward issuing municipal debt on East African financial markets (Bernasconi and Gallo 2017).

The crash-course in becoming-investable offered during the Academies is only the beginning for cities. Those dedicated to becoming investable graduate onto City Creditworthiness Implementation Programs, the goal of which is to, "help participants prepare for, structure, and close market-based financing transactions for climate-smart infrastructure projects" (Podevin 2018, 232). In order to do so:

"the CCI helps city financial officers in conducting thorough reviews of their municipal revenue systems, in understanding how ratings agencies and potential investors assess credit quality, and in taking the first steps to qualify for a rating while recognizing that achieving an investment grade will likely take several years of effort. Improving credit standing is important even where private capital lending is not yet possible because the factors that contribute to creditworthiness can be broadly interpreted to stand for good governance and administration" (Podevin 2018, 232).

This statement, shot through with the concerns of New Institutional Economic (Best, 2014), underlines how various aspects of GSA center on policy reform, even where this will not immediately produce new financial flows but may do so in the future, reforms that are seen as 'no regret' interventions. The policies facilitated through the Academies are consistent with those offered through Development Policy Lending; while GSA may be diffuse across an array of Bank programs, there is internal consistency. In all cases, the debt-bearing city is to be the outcome of technical assistance and lending. Similarly, the Bank desires in client states just what private investors want from cities: predictable regulation and markets that fund municipal contributions to return-generating infrastructure that function as points where investable capital can touch down.

The ideology and practices of GSA are still being deployed, but there is no shortage of examples of the financial mechanisms to be enabled through this process. The Bank's Investing in Urban 
Resilience (2015b) report lists 34 separate financial mechanisms for channeling private capital into cities for resilient infrastructure. Of these, about one third are insurance and disaster relief funding channels while the others are more purely about steering capital into bankable projects. Consider Kampala, which has been enrolled into a variety of Bank urban resilience programs. Kampala is growing rapidly, and its hydraulic infrastructure currently fails to deliver clean drinking water to most residents. In the face of less predictable, more intense rainfall, flood and disease risks proliferate (UN-HABITAT 2009). Following \$33 million in Bank concessional finance to the national government for the 'Kampala Institutional and Infrastructure Development Project', which paid for staff training, IT upgrades, and small infrastructural upgrading for flood relief (World Bank 2015c), Kampala hosted a Creditworthiness Academy for 25 Ugandan municipalities in 2015. Since then, Kampala has become a Bank posterchild for municipal revenue collection. Local government has increased incomes by $250 \%$ since 2012 by separating the tax collection competency from expenditures, poaching staff from other departments to work on revenue collection, implementing an electronic collection system, conducting an ad campaign to raise awareness about tax, among other steps (Andema and Haas, 2018). Meanwhile, Kampala also adopted a municipal PPP policy (World Bank 2017; Painter 2018). Increased revenue without increased spending has led local credit rating agencies to pronounce Kampala a good lending risk; however, Ugandan national policy limits municipal borrowing on capital markets, making Kampala dependent on commercial bank borrowing for now, though calls for financial devolution are growing (Gorelick 2018).

While municipal officials wait for policy changes to enable bond issuance, Kampala has, drawn on technical assistance programs from the Bank to enable future privatization and borrowing. These capacities are pitched at producing a managerial government that can identify infrastructure projects to build municipal resilience - from using hydrological data for planning green-grey flood relief projects to drafting tenders for build-own-operate PPP contracts. At Kampala's Academy the city identified 84 resilience projects in its 'Climate Smart Capital Investment Plan'; further technical assistance aims to refine and prioritize those projects into a pipeline of investable projects (ICED 2017). Ultimately, hydraulic infrastructure PPPs could be financed through a combination of green-labeled general obligation bonds, commercial lending from local and regional banks, and LVC from commercial development on plots previously unsuitable due to flood risk, and the increased tax-take from those developments. Debt could be subsidized through IFC credit guarantees or a sovereign guarantee backstopped by political insurance from the Multilateral Investment Guarantee Agency (a World Bank Group institution). In short, the aim is to build capacity to deploy a diverse financial toolkit to produce cities replete with investment opportunities for regional and international investors.

\section{Conclusion: Capitalist realism and resilience}

The gears for rendering cities around the world investable in the name of climate resilience are turning. However, the current focus is on creating enabling conditions rather than in tracking billions in return-oriented capital into the Global South for resilient infrastructure. If the old structural adjustment was, to a large extent, about reinscribing core-periphery relations through uneven terms of trade, limiting the possibilities for endogenous development in the Global South, and securing Northern access to primary resources (Tsvangirai, in Yeros, 2013), GSA aims to accomplish a similar reinscription by allowing capital to flow into urban built environments, thereby extracting rents from Northern financed, owned, and operated infrastructure while ameliorating structural overaccumulation that has inflated Northern asset 
prices and driven down financial yields. To date, GSA is less about new mechanisms through which the financialization of nature or infrastructure is accomplished, and more a spatial-fix through governance reforms and blended finance. The scalar switch to cities is an important feature for emerging understandings of 'frontier financialization' (Langley 2018). In the logics and practices of GSA, not all 'frontiers' are equally investable, nor do they all promise lucrative returns. Although the concentration of capital and populations in vulnerable cities across the Global South is an opportunity to produce investable enclaves, this turns on making resilience a question of investment. Adaptation then becomes a problem addressed by investors and city elites, rather than those most likely impacted by climate change (Bigger and Millington 2019) or, indeed, those impacted by new urban infrastructure themselves (Betteridge and Webber 2019).

GSA is not yet fully hegemonic, nor does Bank or wider development industry practice encompass these discourses and practices to the exclusion of other modes and models for development; rather, our argument, for now, is circumscribed for practices relating to resilience in cities. The array of programs, facilities, and mechanisms we have presented here, however, is an increasingly critical part of the development industry, aligned with both New Washington Consensus and the Wall Street Consensus. The Bank has scaled up its urban-oriented programs, and has rising targets for its urban resilience agenda; from a baseline of around $\$ 10$ billion in investment in 41 countries from 2011 to 2016, it aims to leverage \$25 billion per year from 2017 to 2022, with projections rising thereafter (World Bank 2015b). If successful, this ambition would represent a dramatic ramp-up in urban infrastructure investment, irrespective of the source, and consolidation of urban resilience as a primary 'product line' for the Bank. While many of the constituent pieces of GSA were developed and expanded under former Director General Kim, the bank has continued to move in this direction under new Director General Malpass who advocates for the "efficient use of capital" (World Bank, n.d.). This direction of travel is troubling and future developments merit careful scholarly attention and policy intervention.

Going forward, we identify three particular areas of research for elucidating the impacts of GSA. First, our approach here has been broad, but grounded research is needed about GSA-enabled investments, the context-dependent ways in which financiers, technocrats and specific financial mechanisms realize urban resilience investments, and how communities are affected by the deployment of infrastructure as a solution to climate-inflected vulnerabilities. Second, forensic accounting is necessary to trace actual capital flows and thereby evaluate the scope and macroeconomic impact of GSA discourses and practices. Third, comparative research could help differentiate contrasting modalities of infrastructure finance and governance. This might take the form of in-country assessments of infrastructure finance through GSA-aligned programs that are also recipients of funding from institutions beyond the western development industry, like the Asian Infrastructure Investment Bank.

In policy terms, we reject the overriding narrative that 'There is No Alternative' to GSA, as well as the various, supposedly post-ideological 'solutions' emanating from the 'Solutions Bank'. Yet, we concur with the Bank that solutions must look to solving the twin problems of project design and development and capital availability for those projects. But, rather than delegate problem-solving to markets (which have manifestly failed to achieve good environmental and development outcomes for the last 40 years), we see much promise in emerging narratives around a global Green New Deal that foregrounds solidarity financing through Northern recognition and recompense for 'climate debts' while delegating the task of identifying critical 
public goods for investment to communities who would benefit (see Aranoff et al 2019). Perhaps the most important area of research, then, is elaborating the contours of how this could be operationalized. Geographers are well situated to imagine and help produce futures beyond the grim narrowness of perpetual austerity.

\section{Acknowledgements}

The authors thank Gareth Bryant, Ilias Alami, Tad Mutersbaugh, Benjamin Neimark, four deeply engaged reviewers and the editorial guidance of James McCarthy for helping to clarify and strengthen the argument of this paper. We are also grateful to World Bank staff who shared their ideas and practices. The authors received funding from the Social Sciences and Humanities Research Council (Canada), the Swedish Research Council, and the American Association of Geographers. 
Adler, D. 2015. “The War for Mexico's Water.” Foreign Policy, July 31, 2015.

https://foreignpolicy.com/2015/07/31/the-war-for-privatization-mexicos-water/.

Andema, F. and A. Haas. 2018. Efficient and effective municipal tax administration: a case study of the Kampala Capital City Authority. London: International Growth Centre.

Arce Lozano, R, and D Davalos. 2019. "Green Finance in Mexico: New Funding Opportunities." Mondaq, 2019. http://www.mondaq.com/article.asp?article_id=825276\&signup=true.

Arnoff, K, A Battistoni, D A Cohen, and T Riofrancos 2019. "A Planet to Win". New York: Verso.

Bernasconi, L. and J. Gallo. 2017. "Cities need good credit scores too. Here's why." https://www.weforum.org/agenda/2017/06/cities-need-good-credit-scores-too/

Best, J. (2014). Governing Failure: Provisional Expertise and the Transformation of Global Development Finance. Cambridge: Cambridge University Press.

Betteridge, B, and S Webber. 2019. "Everyday Resilience, Reworking and Resistance in North Jakarta's Kampungs." Environment and Planning E: Nature and Space: 2(4), 944-966.

Bigger, P, and N Millington. 2019. "Getting Soaked? Municipal Debt, Climate Adaptation and Racialized Austerity." Environment and Planning E: Nature and Space. [Online first]

Christophers, B. 2015. "The Limits to Financialization." Dialogues in Human Geography 5 (2): 183-200.

City Resilience Program. n.d. “CRP Surveys.” n.d. https://public.tableau.com/profile/mary4882\#!/vizhome/CRPSurveyResults-TTLs/Dashboard2.

- n.d. "Private Capital Mobilization in City-Level Engagements, Phase 1: Indicative Assessment of City Readiness." https://www.gfdrr.org/sites/default/files/events/crp-bkk1pvt-cap-city-engagements.pdf.

City Resilience Program. n.d. "Land Value Capture." https://www.gfdrr.org/sites/default/files/LVC_overview_June6.pptx

CityStrength. 2014. "Can Tho, Vietnam: Enhancing Urban Resilience.” Washington DC: World Bank.

Colgen, C. 2002. "Hazardous to Health: The World Bank and IMF in Africa." Washington, D.C: Africa Action

Davis, M. 2006. Planet of Slums. London: Verso.

Denning, S. 2012. "The World Bank to Become a Solutions Bank." Forbes, October 12, 2012. https://www.forbes.com/sites/stevedenning/2012/10/12/the-world-bank-to-become-asolutions-bank/.

Fay, M, and X Opal. 1999. "Urbanization without Growth: A Not so Uncommon Phenomenon." Washington DC: World Bank.

Fine, B. 1999. “The Development State Is Dead - Long Live Social Capital.” Development and Change 30: 1-19.

Gabor, D. 2019. Securitization for Sustainability: Does it help achieve the Sustainable

Development Goals? Berlin: Heinrich Böll Stiftung.

Garcia-Arias, J. 2015. "International Financialization and the Systemic Approach to International Financing for Development." Global Policy 6 (1): 24-33. 
Gifford, L. 2020. 'You can't value what you can't measure: A critical look at forest carbon accounting' Climatic Change. https://doi.org/10.1007/s10584-020-02653-1.

Global Facility for Disaster Reduction and Recovery. 2019. "Resilience Enhancement Track.’https://www.gfdrr.org/en/city-resilience-program/technical-assistance.

Global Facility for Disaster Reduction and Recovery. n.d. "Open Data for Resilience Initiative: Tools and Capacity Building." https://www.gfdrr.org/en/open-data-resilience-initiative-toolsand-capacity-building-0.

Goldman, M. 2005. Imperial Nature: The World Bank and Struggles for Social Justice in the Age of Globalization. New Haven, CT: Yale University Press.

Gorelick, J. 2018. "Supporting the Future of Municipal Bonds in Sub-Saharan Africa: The Centrality of Enabling Environments and Regulatory Frameworks." Environment and Urbanization 30 (1): 103-22.

Harvey, D. 2005. A Brief History of Neoliberalism. Oxford: Oxford University Press.

Hickel, K. 2017. The Divide: A Brief Guide to Global Inequality and Its Solutions. London: Random House.

Infrastructure and Cities for Economic Development. 2017. "Case Study: City Creditworthiness in East Africa.” http://icedfacility.org/wp-content/uploads/2017/12/ICED_Case_CityCreditworthiness-in-East-Africa.pdf.

International Finance Corporation. 2018. "Climate Investment Opportunities in Cities: An IFC Analysis.” Washington DC: International Finance Corporation.

Kentikelenis, A. E., Stubbs, T. H., \& King, L. P. (2016). IMF conditionality and development policy space, 1985-2014. Review of International Political Economy, 23(4), 543-582.

Kim, J. 2017. "Rethinking Development Finance: Speech by World Bank Group President Jim Yong Kim." World Bank. at https://www.worldbank.org/en/news/speech/2017/04/11/speech-by-world-bank-grouppresident-jim-yong-kim-rethinking-development-finance.

Krippner, G. 2005. "The Financialization of the American Economy." Socio-Economic Review 3 (2): 173-207.

Lake, R. W. (2015). The financialization of urban policy in the age of Obama. Journal of Urban Affairs, 37(1), 75-78.

Langley, P 2018. "Frontier Financialization: Urban Infrastructure in the United Kingdom.” Economic Anthropology 5 (2): 172-84.

Leitner, H, E Sheppard, and E Colven. 2017. "Ecological Security for Whom: The Politics of Flood Alleviation and Urban Environmental Injustice in Jakarta, Indonesia." In The Routledge Companion to the Environmental Humanities, edited by U Heise, J Christensen, and M Niemann, 194-205. London: Routledge.

Mawdsley, E 2016.

Mawdsley, E. 2018a. “'From Billions to Trillions': Financing the SDGs in a World 'Beyond Aid."' Dialogues in Human Geography 8 (2): 191-95.

Mawdsley, E. 2018b. Development geography II: financialization. Progress in Human Geography, 42(2), 264-274. 
Mediavilla, J, and J Garcia-Arias. 2019. "Philanthrocapitalism as Neoliberal (Development Agenda) Artefact: Philanthropic Discourse and Hegemony in (Financial for) International Development." Globalizations, 1-19.

Mitchell, K, and M Sparke. 2016. "The New Washington Consensus: Millennial Philanthropy and the Making of Global Market Subjects." Antipode 48 (3): 724-249.

Moody's Investor Services. 2010. "Rating Action: Moody's Assigns a Ba1 Issuer Rating to the Municipality of Lima, Peru." https:/www.moodys.com/research/Moodys-assigns-a-Ba1issuer-rating-to-the-Municipality-of--PR_211725. . 2013. "Rating Action: Moody's Assigns a Baa3 Debt Rating to City of Lima's Upcoming PEN 593 Million Bond Issuance." https://www.moodys.com/research/Moodys-assigns-a-Baa3-debt-rating-to-City-ofLimas--PR_279303.

Naim, M. 2000. "Fads and Fashion in Economic Reforms: Washington Consensus or Washington Confusion?" Third World Quarterly 21 (2): 505-28.

O’Neill, P. 2019. "The Financialization of Urban Infrastructure: A Framework for Analysis." Urban Studies 56 (7): 1304-25.

Painter, D. 2018. "Municipal Financial Sustainability and Financing the City's Sustainability Plans." presented at the GPSC African Regional Workshop, Abidjan, Côte d'Ivoire. https://www.thegpsc.org/sites/gpsc/files/partnerdocs/day_3_dpainter_combined_presentat ion_v2018-05-15.pdf.

Paudyn, B. (2014). Credit ratings and sovereign debt: the political economy of creditworthiness through risk and uncertainty. Springer.

Podevin, J. 2018. “The World Bank City Creditworthiness Initiative: Innovation to Improve Cities' Access to Finance for Low Carbon, Resilient Infrastructure.” In Climate Change and Cities: Second Assessment Report of the Urban Climate Change Research Network, edited by C Rosenzweig, W Solecki, P Romero-Lankao, S Mehrotra, S Dhakal, and S Ibrahim, 232-33. Cambridge UK: Cambridge University Press.

Rodin, J. 2014. The Resilience Dividend: Being Strong in a World Where Things Go Wrong. New York: Public Affairs.

Rosenman, E. 2019. "The Geographies of Social Finance: Poverty Regulation through the 'Invisible Heart' of Markets.' Progress in Human Geography 43 (1): 141-62.

Rozenberg, J, and M Fay. 2019. "Beyond the Gap: How Countries Can Afford the Infrastructure They Need While Protecting the Planet." Washington DC: World Bank.

Salazar, JG. 2007. "Decentralization, Politics and Service Delivery in Mexico." IDS Bulletin 38 (1): 70-76.

Samatar, A. 1993. "Structural Adjustment as Development Strategy? Bananas, Boom, and Poverty in Somalia." Economic Geography 69 (1): 25-43.

Schmidt, J. J., \& Matthews, N. (2018). From state to system: Financialization and the waterenergy-food-climate nexus. Geoforum, 91, 151-159.

Sheppard, E, and H Leitner. 2010. "Quo Vadis Neoliberalism? The Remaking of Global Capitalist Governance after the Washington Consensus." Geoforum 41 (2): 185-94.

Stein, F, and D Sridhar. 2017. "The World Bank Reinvents Itself - and Puts Poverty Reduction at Risk." The Conversation, June 16, 2017. https://theconversation.com/the-world-bankreinvents-itself-and-puts-poverty-reduction-at-risk-79403.

Stiglitz, J. 2002. Globalization and Its Discontents. London: Allen Lane. 
Swaroop, V. 2016. “The World Bank's Experience with Structural Reforms for Growth and Development." Washington DC: World Bank.

Thomas, L. 2018. "The World Bank Is Remaking Itself as a Creature of Wall Street." The New York Times, January 25, 2018. https://www.nytimes.com/2018/01/25/business/worldbank-jim-yong-kim.html.

UN-HABITAT. 2009. "Climate Change Assessment for Kampala, Uganda.” Nairobi, Kenya: UN-HABITAT.

Vasquez, X. 2015. "Investing in Mexico's Infrastructure.” World Policy, February 26, 2015. https://worldpolicy.org/2015/02/26/investing-in-mexicos-infrastructure/.

Webber, S, Leitner, H, and Sheppard, E (Forthcoming) "Wheeling out urban resilience:

Philanthrocapitalism, marketization, and local practice." Annals of the American Association of Geographers

Weber, R. 2010. "Selling City Futures: The Financialization of Urban Redevelopment Policy." Economic Geography 86 (3): 251-74.

Whiteside, H. 2019. "Public-Private Partnerships: Market Development through Management Reform." Review of International Political Economy. [Online first]

Wilder, M, and P Romero-Lankao. 2006. "Paradoxes of Decentralization: Water Reform and Social Implications in Mexico.” World Development 34 (11): 1977-95.

Williamson, J. 2000. "What Should the World Bank Think about the Washington Consensus." The World Bank Research Observer 15 (2): 251-64.

World Bank. 2015a. "Can Tho Urban Development and Resilience Project Information Document." PIDC23544. Washington DC: World Bank.

- 2015b. Investing in Urban Resilience: Protecting and Promoting Development in a Changing World. Washington DC: The World Bank.

- 2015c. "Kampala Institutional and Infrastructure Development Project." Completion Report ICRR14588. Washington DC: World Bank.

- 2017. "From Regulators to Enablers: The Role of City Governments in Economic Development of Great Kampala." Washington DC: World Bank.

—. 2018a. "City Resilience Program 2018 Annual Report." Washington DC: World Bank.

- 2018c. "Financing a Resilient Urban Future." World Bank: Washington, DC.

- 2018b. "Financing for Development at the World Bank Group." Washington DC: World Bank.

- 2019a. "City Resilience Program." https://www.worldbank.org/en/topic/disasterriskmanagement/brief/city-resilienceprogram.

_. 2019b. "The World Bank Group Action Plan on Climate Change Adaptation and Resilience.” Washington DC: World Bank.

- n.d. "City Creditworthiness Initiative: A Partnership to Deliver Municipal Finance." https://www.worldbank.org/en/topic/urbandevelopment/brief/city-creditworthinessinitiative.

- n.d. "David Malpass." https://www.worldbank.org/en/about/people/d/david-malpass. Yeros, P. 2013. The rise and fall of trade unionism in Zimbabwe, Part I: 1990-1995. Review of African Political Economy, 40(136), 219-232. 